\title{
Recent Progress in Lectin-Based Biosensors
}

\author{
Baozhen Wang ${ }^{1,2}$ and Jun-ichi Anzai ${ }^{2, *}$
}

Received: 23 October 2015; Accepted: 2 December 2015; Published: 9 December 2015

Academic Editor: Dusan Losic

1 Department of Nutrition and Food Hygiene, School of Public Health, Shandong University, 44 Wenhua Xilu, Jinan 250012, China; Pauline_111@m.tohoku.ac.jp

2 Graduate School of Pharmaceutical Sciences, Tohoku University, Aramaki, Aoba-ku, Sendai 980-8578, Japan

* Correspondence: junanzai@mail.pharm.tohoku.ac.jp; Tel.: +81-22-795-6841

\begin{abstract}
This article reviews recent progress in the development of lectin-based biosensors used for the determination of glucose, pathogenic bacteria and toxins, cancer cells, and lectins. Lectin proteins have been widely used for the construction of optical and electrochemical biosensors by exploiting the specific binding affinity to carbohydrates. Among lectin proteins, concanavalin A (Con A) is most frequently used for this purpose as glucose- and mannose-selective lectin. Con A is useful for immobilizing enzymes including glucose oxidase (GOx) and horseradish peroxidase (HRP) on the surface of a solid support to construct glucose and hydrogen peroxide sensors, because these enzymes are covered with intrinsic hydrocarbon chains. Con A-modified electrodes can be used as biosensors sensitive to glucose, cancer cells, and pathogenic bacteria covered with hydrocarbon chains. The target substrates are selectively adsorbed to the surface of Con A-modified electrodes through strong affinity of Con A to hydrocarbon chains. A recent topic in the development of lectin-based biosensors is a successful use of nanomaterials, such as metal nanoparticles and carbon nanotubes, for amplifying output signals of the sensors. In addition, lectin-based biosensors are useful for studying glycan expression on living cells.
\end{abstract}

Keywords: lectin; biosensor; concanavalin A; glucose sensor; pathogenic bacteria; cancer cells

\section{Introduction}

Biosensors are fabricated by combining molecular recognition elements, such as enzymes and antibodies, and electrical or optical transducers. Recognition elements are immobilized on the surface of transducers, resulting in reagentless sensors that can be used for determining target molecules without adding reagents in the sample solution. Immobilization of recognition elements without a loss of the biological activity is a prerequisite for successful preparation of any biosensors. Thus, immobilization of recognition elements on the surface of transducers is a key step in constructing high-performance biosensors. Therefore, a variety of protocols have been developed for immobilizing proteins on a solid surface, including irreversible adsorption through hydrophobic and electrostatic forces, chemical cross-linking with divalent reagents, entrapment in polymer networks, and covalent bonding [1-3].

Another protocol for protein immobilization is to use binding proteins as molecular glue that adheres to enzymes and antibodies through biological interactions. Typical examples of such binding proteins include antibody, avidin, and lectin. Antibodies have been widely used to immobilize antigen-tagged proteins [4,5]. Avidin is a glyco-protein isolated from egg white and known to strongly bind biotin or biotin-tagged molecules [6,7]. A variety of biotin-tagged biomolecules have been immobilized on solid surfaces to construct protein architectures and biosensors [8-13]. On the other hand, lectin is a family of sugar-binding proteins found in plants and animals [14]. 
Concanavalin A (Con A) is a typical lectin protein that has been most widely utilized for constructing biosensors. Con A contains four binding sites to sugars such as D-glucose and D-mannose; the binding constants to D-glucose and D-mannose are $0.8 \times 10^{3}$ and $2.2 \times 10^{3} \mathrm{M}^{-1}$, respectively [15-17]. Early works demonstrated that polysaccharides and proteins can be immobilized using Con A onto solid supports without loss of the biological activity [18-20]. An advantage of using Con A in constructing biosensors is that glycoenzymes, such as glucose oxidase (GOx) and horseradish peroxidase (HRP), can be immobilized without labeling because these enzymes intrinsically contain hydrocarbon chains [21-25].

Three different routes are available for immobilizing proteins on the surface of transducers by means of Con A. Glycoproteins or sugar-labeled proteins can be deposited on Con A-adsorbed transducers by simply immersing the transducers in the solution of proteins (Figure 1a). This procedure provides basically a monomolecular layer of the proteins. The amount of immobilized proteins can be enhanced by forming multilayers, in which Con A and proteins are alternately deposited on the surface of transducers in a layer-by-layer (LbL) fashion (Figure 1b). In this protocol, the amount of immobilized proteins depends on the number of layers, enabling precise control of the magnitude of sensor signals. LbL-deposited protein films have recently attracted much attention because of their potential applications to controlled release and biosensors [26-28]. Another protocol relies on cross-linking of glycoproteins with Con A in the mixed solution to form a protein gel layer on the transducer surface (Figure 1c).

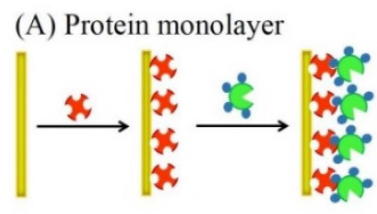

(B) Protein multilayer

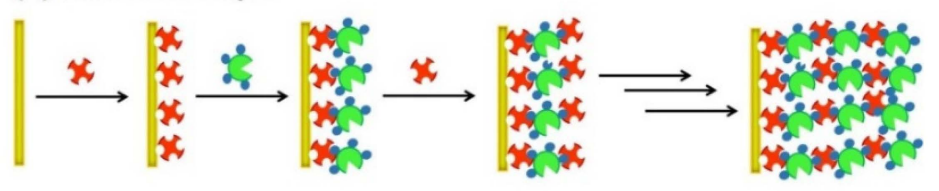

(C) Cross-linked protein layer

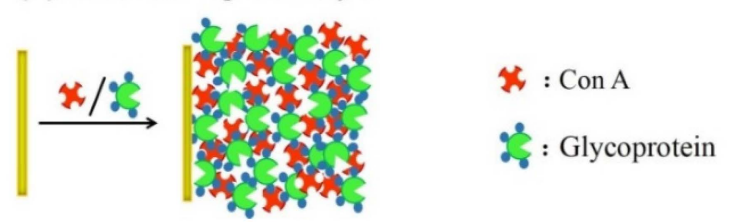

Figure 1. Possible routes for immobilization of glycoproteins by Con A on the surface of solid surface. (A) Monomolecular layer of glycoprotein; (B) layer-by-layer-deposited multilayer film of glycoprotein; and (C) cross-linked multilayer film of glycoprotein.

Lectins are used not only as molecular glue to immobilize proteins but also used as the recognition element of biosensors, because lectins bind carbohydrate chains with high selectivity [29-32]. Thus, lectin-modified electrodes have been used as sensors for the determination of glucose, glycoproteins, as well as cells and microorganisms.

The use of lectins in the development of sugar-sensitive materials for biosensors has been attracting much attention [33-37]. Many different biosensors have been developed using lectin-modified electrodes and optical devices. Therefore, in this review, we focus on progress in the development of lectin-based biosensors in the last several years. Biosensors for the determination of glucose, pathogenic bacteria and toxins, cancer cells, and lectins are discussed. 


\section{Glucose Sensors}

The development of GOx-based glucose sensors has been a focal subject in the field of biosensors [38]. On the other hand, metal and carbon nanomaterials are employed for constructing non-enzymatic glucose sensors [39]. Organic materials such as conducting polymers and phenylboronic acids are also used for developing enzyme-free glucose sensors [40-43]. In this context, early studies demonstrated the utility of Con A in constructing optical and electrochemical glucose sensors [44-51]. For example, Con A was used for immobilizing GOx on the surface of electrodes. In contrast, in non-enzymatic glucose sensors, Con A itself serves as a recognition element for glucose.

A typical example of GOx-based glucose sensor has been prepared by mixing HRP-GOx conjugate, Con A, and chitosan (CS) on the surface of a gold $(\mathrm{Au})$ electrode to form cross-linked HRP-GOx-Con A-CS thin films [52]. The HRP-GOx-Con A-CS films were rather porous and the GOx was catalytic active in the films. Au electrodes modified with the film exhibited amperometric response to glucose over the concentration range of $1.0 \times 10^{-6}-2.2 \times 10^{-4} \mathrm{M}$ with a lower detection limit of $6.7 \times 10^{-7} \mathrm{M}$. The response of the sensor was satisfactorily fast ( 10 s) owing to high porosity of the HRP-GOx-Con A-CS film. A variety of glucose sensors were constructed by immobilizing GOx through Con A linkages on $\mathrm{Au}$ / platinum (Pt) hybrid nanostructures [53], carbon nanotube-supported Pt nanoparticles [54], and Prussian blue/graphene composite films [55]. The linear response ranges of the glucose sensors were $3.0 \times 10^{-6}-2.3 \times 10^{-3} \mathrm{M}$ [53], $1.2 \times 10^{-6}-2.0 \times 10^{-3} \mathrm{M}$ [54], and $2.5 \times 10^{-5}-3.2 \times 10^{-3} \mathrm{M}$ [55], respectively. The lower detection limits of the sensors were in the range of $4.0 \times 10^{-7}-1.0 \times 10^{-5} \mathrm{M}$. Zinc oxide nanorods modified with $\mathrm{Au} / \mathrm{Pt}$ composite were also combined with GOx-Con A layers to fabricate glucose sensors, which exhibited a response to glucose from $1.8 \times 10^{-6}$ to $5.1 \times 10^{-3} \mathrm{M}$ and a lower detection limit was $0.6 \times 10^{-6} \mathrm{M}$ [56]. Bienzyme sensors consisting of GOx and HRP were prepared based on LbL deposition of Con A and enzymes on the surface of electrode and the electrochemical response to phenols, aromatic amines, and sulfides was studied $[57,58]$.

GOx-based electrochemical glucose sensors are often operated in the presence of electron transfer mediators, such as metal complexes, that can shuttle electrons from reduced form of GOx to electrode. The electron transfer mediators are co-immobilized on the surface of electrodes together with GOx, providing mediator-type glucose sensors. On this line, mediator-type glucose sensors can be constructed using redox-active Con A modified with electron transfer mediators for immobilizing GOx on electrode. According to this concept, Azzaroni and Battaglini groups have recently constructed biosensor platforms using redox-active Con A modified with osmium bipyridine complex, [Os(bpy $)_{2}$ Clpy] [59-62]. The [Os(bpy ${ }_{2} \mathrm{Clpy}$ ]-modified Con A was used to immobilize GOx on the surface of Au electrode (Figure 2). Electrochemical and optical studies showed that [Os(bpy) $\left.{ }_{2} \mathrm{Clpy}\right]-$ modified Con A successfully accelerates electron transfer from GOx to electrode, although only a fraction (i.e., $20 \%-30 \%$ ) of the redox sites is involved in the electron transfer. The same group showed that HRP can be assembled together with GOx using [Os(bpy ${ }_{2} \mathrm{Clpy}$-modified Con A to provide bienzyme glucose sensors [60]. In another study, redox-active Con A bearing daunomycin was prepared to evaluate interactions between Con A and ovalbumin [63]. The redox response of the daunomycin-labeled Con A decreased in the presence of $1.5 \times 10^{-10}$ to $1.5 \times 10^{-9} \mathrm{M}$ ovalbumin as a result of specific binding of ovalbumin to Con A. Nanomaterials such as graphene oxide sheets [64] and aluminum oxide particles [65] were successfully coupled with Con A to provide support for enzyme immobilization. $\mathrm{pH}$ and thermal stability of enzymes were improved by using the nanomaterials as support. Apart from Con A-mediated glucose sensors, HRP-modified electrodes were prepared through Con A complexation to study electron transfer reactions between HRP and electrode [66-68].

Con A can be used as glucose recognition element for the construction of non-enzyme glucose sensors by taking advantages of glucose selectivity of Con A. Glucose sensors have been constructed based on a variety of signal transduction mechanisms, including electrochemistry, colorimetry, fluorometry, and gravimetry. For example, capacitive glucose sensors were constructed 
by immobilizing Con A on a poly(tyramine)/Au nanoparticles-coated electrode [69]. The capacitive glucose sensors showed a response to $1.0 \times 10^{-6}-1.0 \times 10^{-2} \mathrm{M}$ glucose, though the response was rather slow (ca. $15 \mathrm{~min}$ ). Amperometric sensors using thionine-modified electrodes were also reported [70,71]. The thionine-modified electrodes exhibited responses to glucose in the ranges of $1.0 \times 10^{-6}-1.0 \times 10^{-4} \mathrm{M}$ with a detection limit of $7.5 \times 10^{-7} \mathrm{M}[70]$ and $5.0 \times 10^{-7}-1.55 \times 10^{-5} \mathrm{M}$ with a detection limit of $2.2 \times 10^{-7} \mathrm{M}$ [71]. In another example, surface-confined Con A served as a $\mathrm{pH}$-sensitive ion-gate that blocks redox-active ions depending on $\mathrm{pH}$ of the solution [72] (Figure 3). Thus, voltammetric signal of the Con A-confined electrode depends on GOx-catalyzed reaction of 1-10 mM glucose in solution, because the enzymatic reaction produces an acidic product, i.e., gluconic acid. Urea sensors can also be constructed using this system by combining with urease. A drawback of this system is that redox-active species, ferricyanide ions, have to be added in the sample solution.

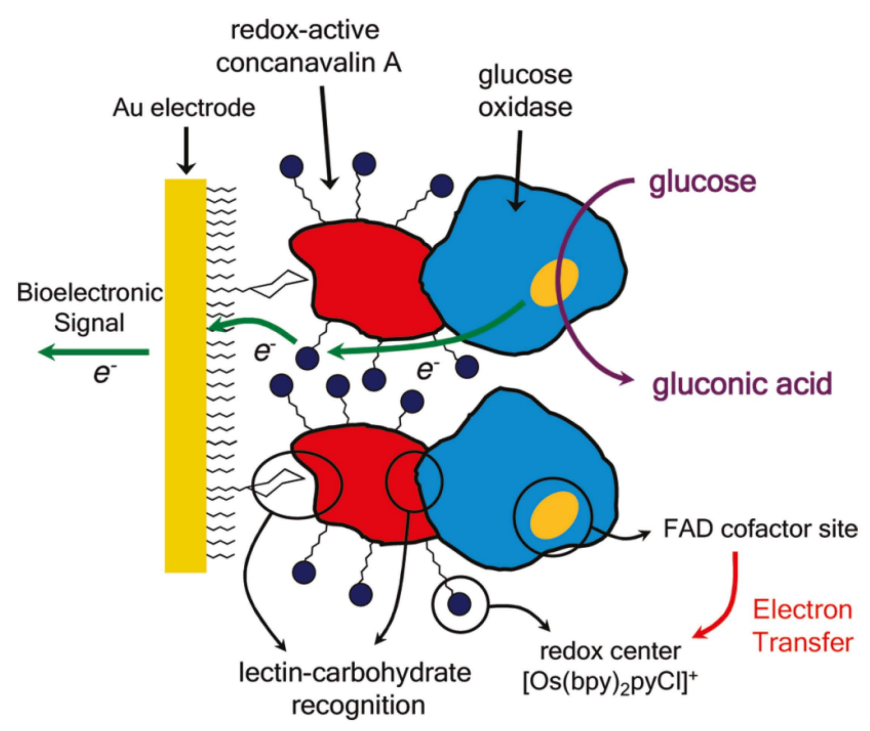

Figure 2. A glucose sensor based on redox-active Con A and GOx. Reprinted with permission from Langmuir. Copyright 2010 American Chemical Society [59].

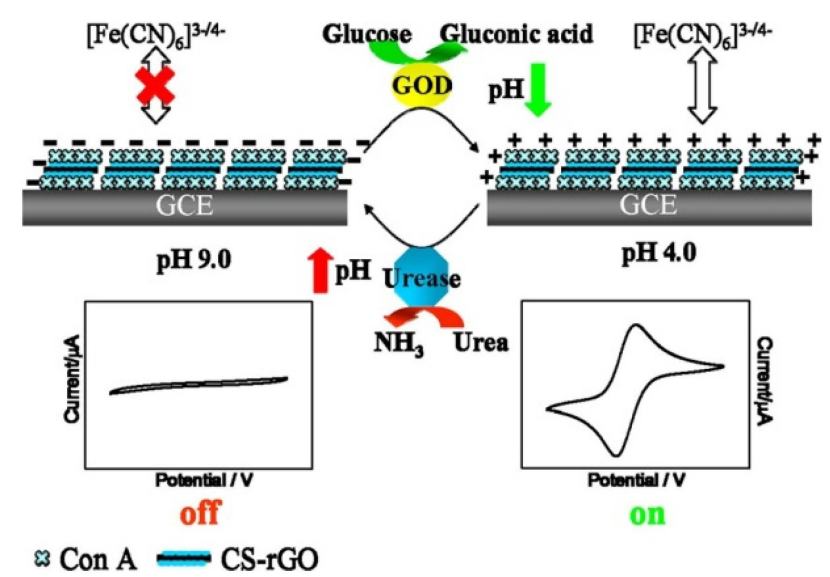

Figure 3. Con A-coated glassy carbon electrode as a $\mathrm{pH}$-sensitive ion gate for glucose and urea sensing. Reprinted with permission from Analytical Chemistry. Copyright 2014 American Chemical Society [72].

Mannose-coated Au nanoparticles were used to develop a colorimetric sensor for glucose [73]. The addition of $\mathrm{Con} \mathrm{A}$ in the $\mathrm{Au}$ nanoparticles dispersion induced aggregation of the $\mathrm{Au}$ 
nanoparticles as a result of cross-linking by Con A, whereas aggregation was suppressed in the presence of glucose due to the competitive binding of glucose to Con A. The aggregated Au nanoparticles were detected through color changes which originated from the shift of surface plasmon absorption band. The colorimetric sensor detected glucose in human serum in the range of $500-4000 \mu \mathrm{g} / \mathrm{mL}$ within $10 \mathrm{~min}$ with a lower detection limit of $363 \mu \mathrm{g} / \mathrm{mL}$. In a similar strategy, fluorescence resonance energy transfer (FRET) between two quantum dots modified with Con A and glucose was studied in the presence of glucose [74]. A needle-type optical biosensor for continuous glucose monitoring was fabricated by combining an optical fiber probe with syringe needles [75]. The optical fiber probe was modified with a thin film composed of Con A and mannose-modified bovine serum albumin (m-BSA). The layer thickness of the m-BSA/Con A conjugate depends on the concentration of glucose in sample solution as a result of the competitive binding of glucose to Con A, inducing a shift in the wavelength of the guided light. The sensor was able to monitor the concentration of glucose in blood in the range of $10-500 \mathrm{mg} / \mathrm{dL}$ with response time of $15 \mathrm{~min}$. This sensor may be promising for clinical applications because the detection range covers the physiological relevant level of blood glucose.

A quartz crystal microbalance (QCM) has been used to develop gravimetric glucose sensors by immobilizing dextran/Con A conjugates on the surface of quartz resonator [76]. The dextran/Con A conjugates decompose upon exposing the resonator to glucose, resulting in changes in the resonance frequency of QCM. Equilibrium constants in the binding of Con A and saccharides were determined by recording changes in the resonance frequency associated with the binding and release of saccharides on Con A-modified quartz resonator [77]. In addition, silicon nanowire-based field-effect transistors [78] and surface plasmon resonance (SPR) sensors [79] were also used for the evaluation of carbohydrate-lectin interactions.

\section{Pathogenic Bacteria and Toxin Sensors}

The detection of pathogenic bacteria is a prerequisite for food and water safety, disease diagnostics, process control in food and pharmaceutical industries, and so forth. Conventional methods for bacteria detection, such as culture and colony counting [80] and enzyme-linked immunosorbent assay [81] are somewhat laborious and time-consuming. Consequently, alternative methods are required for the rapid and reliable detection of bacteria. For this goal, use of lectin-modified sensors may be a promising approach because carbohydrate chains are often expressed on the surface of bacteria.

Several groups have reported lectin-based bacteria sensors. Pingarrón and coworkers developed electrochemical impedance sensors for the detection of Escherichia coli (E. coli) using screen-printed $\mathrm{Au}$ electrodes [82]. Con A was added to sample solutions containing E. coli to form E. coli-Con A aggregates, which were then adsorbed to the electrode. The electron transfer resistance of the electrode linearly depended on the logarithmic concentration of E. coli over $5.0 \times 10^{3}-5.0 \times 10^{7}$ colony forming units $(\mathrm{cfu}) / \mathrm{mL}$. Interestingly, bacteria adsorption to the electrode was negligible without Con A. The authors evaluated the electrochemical responses of the sensor to aggregates formed between nine kinds of lectins and three different bacteria, i.e., E. coli, Staphilococcus aureus (S. aureus), and Mycobacterium phlei. Principal component analysis allowed classification of the bacteria. Another study also used electrochemical impedance spectroscopy for the detection of E. coli, in which antibodies were used as E. coli-recognition elements in place of Con A [83]. An E. coli sensor based on a quinone-fused poly(thiophene)-coated Au electrode has recently been reported [84]. The surface of the Au electrode was coated with electrochemically-polymerized poly(thiophene) film, followed by substitution with mannose residues (Figure 4). E. coli was captured on the electrode through two different routes, i.e., a direct binding and Con A-mediated binding. This sensor can be operated both in electrochemical and gravimetric modes. In the electrochemical measurement, the peak current in square wave voltammetry of the sensor decreased with increasing the concentration of $E$. coli owing to the disturbed electron transfer of quinone-fused thiophene moiety. In the QCM detection mode, 
on the other hand, the resonance frequency of the sensor changed depending on E. coli concentration. The lower detection limits of the sensor were 25 and 50 cells $/ \mathrm{mL}$ in the electrochemical and QCM detections, respectively. Ferrocene-tagged boroxanol pentamer (Fc-pentaBZE) was synthesized by Scheller and coworkers for the development of electrochemical displacement sensors for E. coli [85]. Fc-pentaBZE was immobilized onto a mannose monolayer-coated electrode as a redox-active marker. It is known that boroxanol and boronic acids covalently bind diol compounds such as sugars by forming boronate ester linkage [86]. The immobilized Fc-pentaBZE was displaced by E. coli or Con A upon immersing the electrode in the solution containing E. coli or Con A, resulting in the changes in redox signals of Fc-pentaBZE. The lower detection limit of this sensor for E. coli was approximately $6 \times 10^{2}$ cells $/ \mathrm{mL}$. In this context, use of synthetic lectins such as boroxanol- and boronic acid-modified proteins and polymers may be interesting [87-91]. These materials are endowed with sugar-binding ability because boronic acids form cyclic ester bonds with 1,2- and 1,3-diol compounds including sugars. A variety of synthetic lectins have been used for constructing sugar-sensitive systems [92-97]. Future applications of synthetic lectins to biosensors would be promising.

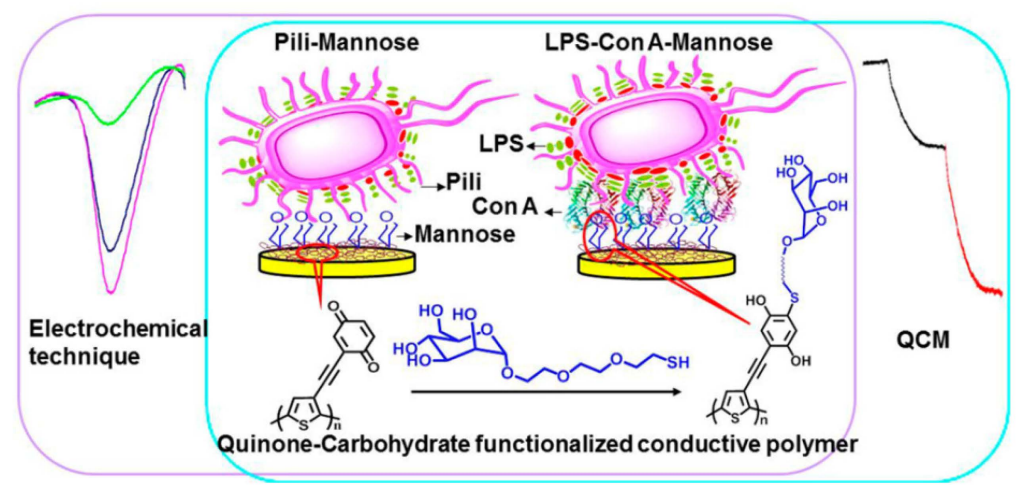

Figure 4. An E. coli sensor based on a quinone-fused poly(thiophene) film-coated electrode and its electrochemical and gravimetric responses. Reprinted with permission from Analytical Chemistry. Copyright 2015 American Chemical Society [84].

A wireless magnetoelastic sensor for E. coli O157:H7 was developed based on Con A- and chitosan-modified magnetic $\mathrm{Fe}_{3} \mathrm{O}_{4}$ nanoparticles [98,99]. An advantage of magnetoelestic sensors is that no physical contact between the sensor probe and the detection system is needed because the sensors require no internal power source. For constructing Con A-mediated sensors, $\mathrm{Fe}_{3} \mathrm{O}_{4}$ nanoparticles were modified with mannose and Con A simultaneously. The resonance frequency of the probe changed upon binding E. coli, enabling determination of E. coli concentration. The sensor exhibited a linear response to $E$. coli over the logarithmic concentration of $6.0 \times 10-6.1 \times 10^{9}$ cells $/ \mathrm{mL}$. Likewise, a variety of E. coli sensors were developed using lectins on the basis of colorimetry [100], flow cytometry [101], and microscopy [102].

Bacterial toxins can be detected through lectin complexation because bacterial toxins often contain sugar moiety as a component. For example, lipopolysaccharides (LPS) located on the outer membrane of Gram-negative bacteria and lipoteichoic acid (LTA), which is composed of glycerolphosphate and saccharides, found in Gram-positive bacteria have been made subject to lectin-mediated detection. Andrade and coworkers developed electrochemical sensors sensitive to LPS from E. coli and LTA from S. aureus [103]. They prepared Con A/poly(aniline) film-coated electrodes and their impedimetric response was recorded in the presence of bacterial toxins. The charge transfer resistance of the Con A-modified electrode significantly increased upon binding the bacterial toxins in the range of 50-200 $\mathrm{gg} / \mathrm{mL}$. On the other hand, LPS sensors prepared using Con A-confined electrodes were used for the assay of activity of antibiotics [104]. The response of the Con A-modified sensor to E. coli was monitored in the presence of antibiotics. The output signals 
originating from LPS of E. coli reduced to $23 \%, 27 \%$ and $38 \%$ after 18 -h incubation of E. coli in the presence of ciprofloxacin, ceftriaxone, and tetracycline, respectively. Thus, Con A-modified sensors are useful for evaluating the antibiotic activity of drugs.

The interactions between hemagglutinin (HA) from human influenza virus and several affinity ligands were studied using surface plasmon resonance (SPR) sensors for screening suitable ligands for the development of influenza virus sensors [105]. HA is an immunogenic glycoprotein found on the surface of influenza virus. Lectins such as wheat germ agglutinin (WGA), Maackia amurensis lectin (MAL), Sambucus nigra agglutinin (SNA), and Con A as well as sialic acid derivatives were tested as candidates for the ligand. Among them, 6'-sialyllactose-ovabumin conjugate was best suited for constructing influenza virus sensors. The SPR sensors were successfully used for analyzing HA in the range of $10-100 \mu \mathrm{g} / \mathrm{mL}$. It is also possible to use metal-clad waveguide sensors, which rely on refractivity changes, for constructing Con A-mediated biosensors [106]. Potential use of the waveguide sensors for label-free measurement of the viability of animal cells, which were attached to the surface of sensor probe through Con $\mathrm{A}$, was suggested.

$\mathrm{Fe}_{3} \mathrm{O}_{4} / \mathrm{MnO}_{2}$ nanoparticles modified with ferrocene $(\mathrm{Fc})$ and Con A were used for enhancing the output signals of electrochemical bacteria sensors [107]. Target bacteria, Deslforibrio caledoiensis (D. caledoiensis), were adsorbed to Con A-immobilized glassy carbon electrode and the electrode was incubated in the solution of $\mathrm{F} c / \mathrm{Con} \mathrm{A}$-modified $\mathrm{Fe}_{3} \mathrm{O}_{4} / \mathrm{MnO}_{2}$ nanoparticles. The electrochemical response of the electrode increased with increasing the D. caledoiensis concentration in the range of $1.0 \times 10^{3}-1.0 \times 10^{8} \mathrm{cfu} / \mathrm{mL}$. Use of $\mathrm{Fc}$ as electrochemical redox marker is a promising approach to develop highly sensitive amperometric and voltammetric biosensors [108].

Electrochemical impedance sensors sensitive to serum proteins from patients infected with dengue virus have been reported [109-111]. The sensor was prepared by coating the surface of $\mathrm{Au}$ electrode with a lipid membrane doped with Con A. The sensors exhibited different responses to four serotypes of dengue virus, resulting in the classification of the type of dengue virus. An interesting protocol for impedimetric sensing of avian influenza virus was developed using magnetic beads modified with avian influenza virus H5N1-specific aptamer (Figure 5) [112]. The modified beads were used for binding influenza virus, followed by conjugation with Con A, GOx, and Au nanoparticles to provide a nanocomposite. The nanocomposite was transferred to a glucose solution to induce GOx-catalyzed oxidation reaction of glucose, resulting in the enhancement of ionic strength due to enzymatically-produced gluconic acid. Thus, impedance of an interdigitated array electrode decreased depending on the amount of GOx on the nanocomposite which, in turn, depends on the concentration of influenza virus in the sample solution. This sensor exhibited a linear response to avian influenza virus H5N1 in the logarithmic concentration of $1.0 \times 10^{-3}-1.0 \times 10^{0}$ hemagglutination units (hau) with a detection limit of $8.0 \times 10^{-4}$ hau. A merit of this protocol is that only an unmodified electrode is required for measuring the electrochemical impedance and the nanocomposites can be prepared separately. Other glycoproteins such as transferrin and immunoglobulin were also made subject to electrochemical determination on Con A-modified electrodes [113-115].
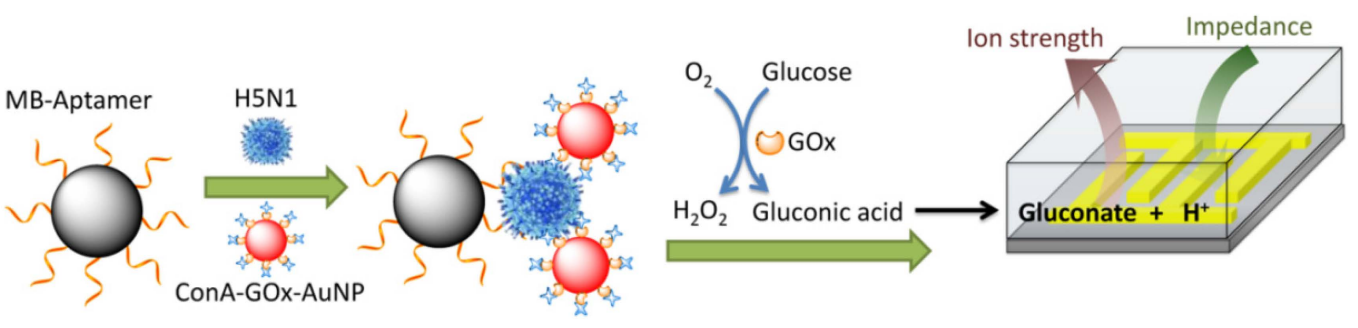

Figure 5. Avian influenza virus sensing based on nano-composites consisting of GOx, Con A, and Au nanoparticles. Reprinted with permission from Analtical Chemistry. Copyright 2014 American Chemical Society [112]. 


\section{Cytosensors}

Cytosensors, i.e., sensors for detecting cells, have been constructed using lectin-modified electrodes by exploiting selective binding of lectins to hydrocarbon chains expressed on the surface of cells. Target cells are bound to the lectin-modified cytosensors to induce changes in electrochemical signals, depending on the number of cells in the sample solutions. Therefore, cytosensors can be used for the quantitative determination of cells. In addition, cytosensors are useful for the profiling of hydrocarbon chains expressed on cell surface because binding affinity of lectins significantly depends on the type of components of hydrocarbon chains.

Recently, much attention has been devoted to the important role of glycoproteins and glycolipids on the surface of cancer cells in relation to cancer therapeutics and diagnosis [116]. In this context, lectin-modified electrodes have been studied to develop cytosensors for detecting cancer cells. Electrochemical cytosensors were constructed using Con A-modified Au electrode coupled with Au nanoparticles coated with Con A and ferrocenylhexanethiol (Fc-SH) [117]. The Con A-modified electrode was first incubated in the sample solution to bind target cancer cells (K562 leukemic cells), followed by a further deposition of the Au nanoparticles to enhance output signal of the sensor. The voltammetric response of the sensor, which originates from redox reactions of Fc moieties, depended on the cell concentration in the range of $1.0 \times 10^{2}-1.0 \times 10^{7}$ cells $/ \mathrm{mL}$. Con A-modified $\mathrm{Au}$ electrodes can be used for impedimetric detection of cancer cells [118]. The charge transfer resistance of the sensor was dependent on the number of human liver cancer cell Bel-7404 in sample solution. The lower detection limit of the sensor was 234 cells $/ \mathrm{mL}$. Zucolotto and coworkers used a galactose-selective lectin jacalin for constructing impedimetric sensors for monocytic leukemic cells THP-1 and myeloblastic cells OCl-AMI3 [119] (Figure 6). The jacalin-based sensors differentiated leukemic cells from healthy monocyte cells with detection limits of $3 \pm 1$ cells $/ \mathrm{mL}$ for THP- 1 and $4 \pm 1$ cells $/ \mathrm{mL}$ for OCl-AMI3. Furthermore, QCM sensor was useful for evaluating changes of carbohydrate chains of cancer cells associated with tumor growth and metastasis. In fact, Pei and coworkers immobilized an epidermoid carcinoma cell line (A-4531) and a breast adenocarcinoma cell line (MDA-MB-468) on quartz crystals to evaluate the binding of lectins [120]. The gravimetric response of the QCM sensors was sensitive to the glycosylation changes of the cells associated with cancer progression and development.
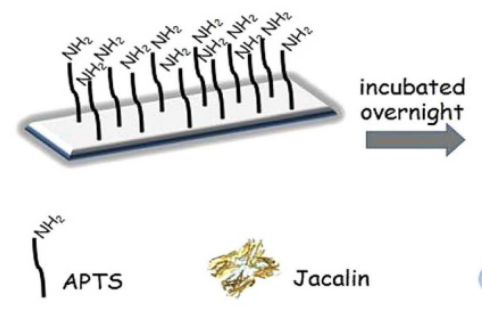

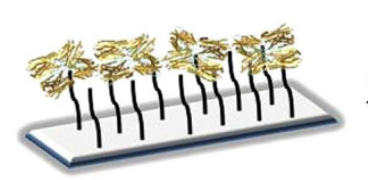
for $15 \mathrm{~min}$

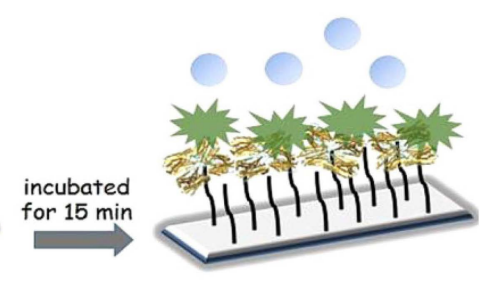

MN cells

Leukemic cells

Figure 6. Preparation of impedimetric cytosensors based on a jacalin-modified electrode for the determination of cancer cells. Reprinted with permission from ChemElectroChem. Copyright 2015 Wiley-VCH Verlag GmbH and Co. [119].

A strategy for signal amplification in the detection of cancer cells was proposed based on Con A-modified composite materials consisting of carbon nanotubes and Au nanoparticles combined with quantum dots [121] (Figure 7). The sensor showed an electrochemical response to model cancer cells (CCRF-CEM cells) in the range of $1.0 \times 10^{2}-1.0 \times 10^{6}$ cells $/ \mathrm{mL}$ and the detection limit was 50 cells $/ \mathrm{mL}$. The response range and detection limit of the sensor in fluorescence response was almost same to those of the electrochemical response. A key role of the aptamer-DNA concatamer quantum dots in the highly-sensitive determination of the cancer cells was suggested. 
Nanomaterial-based cytosensors for the detection of human lung cancer cells, 95-D and H1299, was reported [122]. The cytosensor was constructed by depositing polymer-coated carbon nanotubes, glutathion-protected Au nanoparticles, and Con A successively on the surface of a glassy carbon electrode. The sensor was exposed to a sample solution containing target cancer cells and mannose/thionine-modified nanoparticles, in which nanoparticles and cancer cells competitively bind to Con A on the sensor surface. Voltammetric response of the sensor, originating from redox reactions of thionine, was reversely dependent on the concentration of cancer cells in the sample solution. The sensor showed linear calibration graphs for the logarithmic concentrations ranging from $1.7 \times 10^{3}$ to $1.5 \times 10^{8}$ cells $/ \mathrm{mL}$ for 95 -D with a lower detection limit of 580 cells $/ \mathrm{mL}$ and from $2.5 \times 10$ to $1.0 \times 10^{6}$ cells $/ \mathrm{mL}$ for H1299 with the detection limit of 12 cells $/ \mathrm{mL}$. In a similar strategy using $\mathrm{Au}$ nanoparticle/quantum dot composites, A549 lung cancer cells and QGY-7701 liver cancer cells in the concentrations ranging from 10 to $10^{7}$ cells $/ \mathrm{mL}$ and from $10^{4}$ to $10^{7}$ cells $/ \mathrm{mL}$, respectively, were detected based on the fluorescence emission of the quantum dots [123]. Other nanomaterials useful for enhancing the response of lectin-based cytosensors include nanocomposites comprising $\mathrm{Ru}(\mathrm{bpy})_{3}{ }^{2+}$-doped $\mathrm{Au}$ /silica nanoparticles [124], $\mathrm{HRP} /$ aptamer-modified $\mathrm{Au}$ nanoparticles [125], protein-modified silver nanoflowers [126], and GOx-modified $\mathrm{Au}$ nanoparticles [127]. $\mathrm{Li}$ and coworkers demonstrated that chemiluminescence biosensors based on the $\mathrm{Ru}(\mathrm{bpy}){ }_{3}{ }^{2+}$-doped $\mathrm{Au}$ / silica nanoparticles can be used for detecting $\mathrm{K} 562$ cells in the range of $1.0 \times 10^{3}-1.0 \times 10^{7}$ cells $/ \mathrm{mL}$ with a detection limit of 600 cells $/ \mathrm{mL}$ [124]. The same group further improved the detection limit of human acute lymphoblastic leukemia cells down to 10 cells $/ \mathrm{mL}$ [125] and that of K562 cells to 18 cells/mL [127]. On the other hand, silver nanoflower-based cytosensors detected human colon cancer cells (DLD-1) in the concentration ranging from $1.35 \times 10^{2}$ to $1.35 \times 10^{7}$ cells $/ \mathrm{mL}$ with a detection limit of 40 cells $/ \mathrm{mL}$ [126].

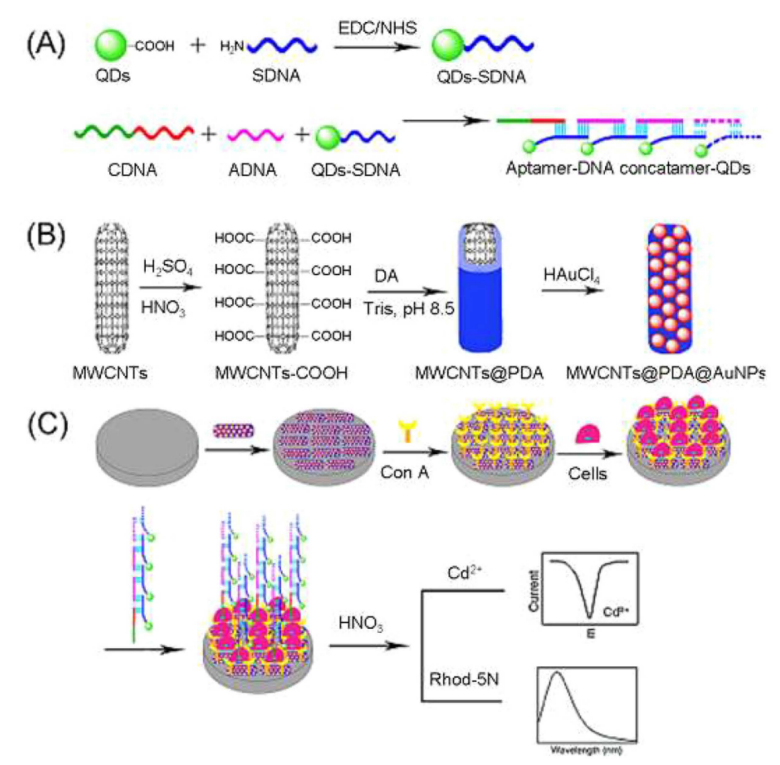

Figure 7. Preparation of nanocomposite-based cytosensors. Precedures for (A) preparing aptamer-DNA concatamer quantum dots by coupling of quantum dot and single-strand DNA followed by hybridization with aptamer and complementary DNAs; (B) preparing $\mathrm{Au}$ nanoparticles-modified carbon nanotubes by coating with poly(dopamine) film and Au deposition; and (C) preparing nanocomposite-modified electrodes by successive deposition of $\mathrm{Au}$ nanoparticles-modified carbon nanotubes, Con $\mathrm{A}$, and target cells, and aptamer-quantum dots composites on the surface of a glassy carbon electrode. The electrode was immersed in $\mathrm{HNO}_{3}$ solution to dissolve the residual quantum dots and then the concentration of cells was determined with electrochemical or fluorescence method. Reprinted with permission from Analytical Chemistry. Copyright 2013 American Chemical Society [121]. 


\section{Lectin Sensing}

Biosensors sensitive to lectin can be prepared by using carbohydrates as recognition elements. In fact, a variety of devices have been developed by immobilizing carbohydrate chains on the surface of electrode and other transducers. A prototype of lectin sensor was constructed by modifying the surface of Au electrode with monosaccharide-quinone hybrids (Figure 8) [128]. In this study, glucose-quinone and galactose-quinone hybrids were used to form monomolecular layers sensitive to specific lectins, Con A and peanut agglutinin (PNA), respectively. The voltammetric signals of the sensors arising from quinone moieties significantly decreased upon binding specific lectin, whereas the response to non-specific lectin was negligible. The results clearly demonstrated that specific epimeric sugars, i.e., glucose or galactose, are discriminated by lectin on the sensor. Au film-coated quartz crystal probes coated with a mannose-quinone functionalized poly(thiophene) film was likewise used to construct lectin sensors [129]. This sensor can be operated in electrochemical as well as gravimetric (i.e., QCM) detection modes. The sensor exhibited dynamic ranges of $0.5-17.5 \mathrm{nM}$ in the electrochemical mode and $0.5-4.5 \mathrm{nM}$ in the QCM mode, respectively, in the detection of Con A.
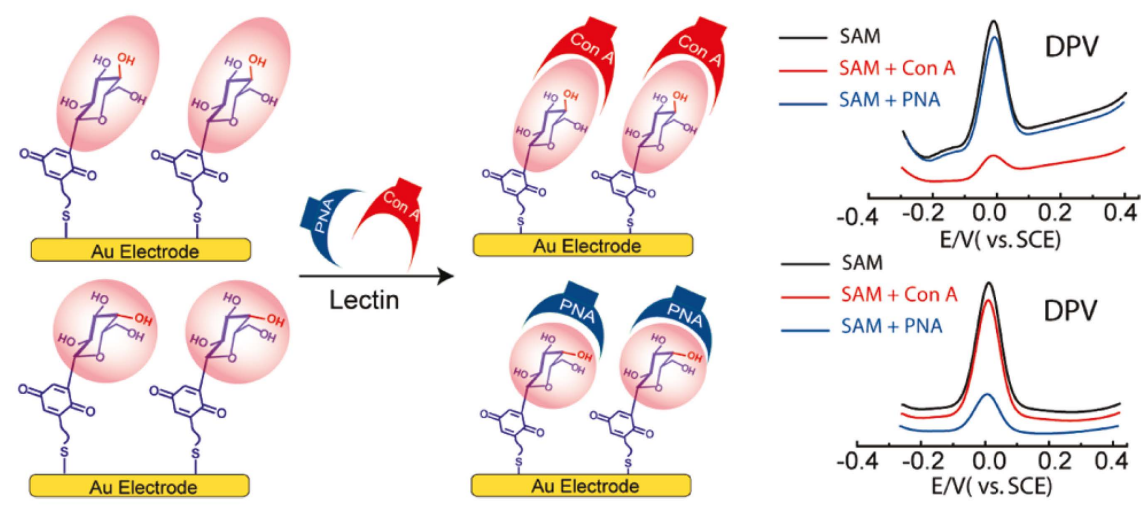

Figure 8. Epimeric monosaccharide-quinone hybrid monolayer-modified Au electrodes for lectin sensing. Reprinted with permission from Journal of the American Chemical Chemistry. Copyright 2011 American Chemical Society [128].

A variety of materials have been used to construct lectin sensors, including self-assemblies of glucose and mannose derivatives [130,131], glycosylated poly(aniline)s [132,133], and glycolipid vesicles [134]. Among the above sensors, it is noteworthy that the lower detection limit of poly(aniline)-based Con A sensor was highly improved, i.e., $1.0 \times 10^{-12} \mathrm{M}$ [132]. Lectin-induced decomposition reaction of redox-active daunomycin-doped micells was also used for the detection of Con $\mathrm{A}$ in the range of $2.0 \times 10^{-9}-8.0 \times 10^{-8} \mathrm{M}$ [135].

Electro-chemiluminescence (ECL)-based lectin sensing was reported by Chen and coworkers [136-138]. The ECL-based system was constructed using nanocomposites comprising graphene, Au nanoparticles, and GOx, in which ECL signal significantly decreased upon binding Con A. Thus, the ECL-based sensors could detect Con A in the range of $0.1-100 \mathrm{ng} / \mathrm{mL}$ [136], $1.0-20 \mathrm{ng} / \mathrm{mL}$ [137], and $0.05-100 \mathrm{ng} / \mathrm{mL}$ [138]. In addition, fluorescence-based systems sensitive to lectins were constructed based on carbohydrate polymers [139] and carbohydrate-capped $\mathrm{Au}$ nanoparticles [140]. The carbohydrate polymers and carbohydrate-capped Au nanoparticles could be used for detecting Con A in the ranges of 1-250 $\mathrm{nM} \mathrm{[139]} \mathrm{and} \mathrm{0.1-500} \mu \mathrm{g} / \mathrm{mL}$ [136], respectively. These materials would be useful for constructing optical sensors if they are combined with appropriate optical devices. 


\section{Conclusions}

Biosensors can be constructed through selective complexation between lectins and carbohydrate chains. The usefulness of the lectin-carbohydrate affinity for constructing biosensors is that any sugar-tagged proteins can be immobilized on the surface of electrochemical and optical transducers. Furthermore, some enzymes, such as GOx and HRP, can be used directly to construct biosensors without labeling owing to their intrinsic hydrocarbon chains. It is an advantage of lectin-carbohydrate systems that the whole process of enzyme immobilization can be carried out under mild aqueous conditions. A versatility of lectins in the recognition of carbohydrates provides another advantage. In other words, lectins are used not only as molecular glue for protein immobilization but lectins serve as recognition element of biosensors. In fact, Con A-modified electrodes are used to detect pathogenic bacteria and cancer cells, in which Con A selectively binds carbohydrate chains located on the surfaces of bacteria and cancer cells. One of the recent trends in the development of lectin-based biosensors is a successful use of metal and carbon nanomaterials for amplifying the output signals of sensors. The nanomaterials make it possible to accumulate significant amounts of optically- and electrochemically-active compounds on the sensors, enabling signal amplification. Au nanoparticles and carbon nanotubes are used for this purpose.

Acknowledgments: This work was supported in part by a Grant-in-Aid (426670010) from the Japan Society for the Promotion of Science.

Author Contributions: The planning of the work was carried out by Jun-ichi Anzai. The manuscript was prepared by Baozhen Wang and Jun-ichi Anzai.

Conflicts of Interest: The authors declare no conflict of interest.

\section{References}

1. Scheldon, R.A.; Schoevaart, R.; van Langen, L.M. Cross-linked enzyme aggregates (CLEAs): A novel versatile method for enzyme immobilization (a review). Biocatal. Biotransform. 2005, 23, 141-147. [CrossRef]

2. Balamurugan, S.; Obubuafo, A.; Soper, S.A.; Spivak, D.A. Surface immobilization methods for aptamer diagnostic applications. Anal. Bioanal. Chem. 2008, 390, 1009-1021. [CrossRef] [PubMed]

3. Ates, M. A review study of (bio)sensor systems based on conducting polymers. Mater. Sci. Eng. C 2013, 33, 1853-1859. [CrossRef] [PubMed]

4. Katz, E.; Willner, I. Amperometric amplification of antigen-antibody association at monolayer interfaces: Design of immunosensor electrodes. J. Electroanal. Chem. 1996, 418, 67-72. [CrossRef]

5. Hoshi, T.; Saiki, H.; Anzai, J. Preparation of spatially ordered multilayer thin films of antibody and their binding properties. Biosens. Bioelectron. 2000, 15, 623-628. [CrossRef]

6. Wilchek, M.; Bayer, E.A. The avidin-biotin complex in bioanalytical applications. Anal. Biochem. 1988, 171, 1-32. [CrossRef]

7. Xing, Y.; Liu, L.; Zhao, D.; Yang, Y.; Chu, X. Synthesis of water-dispersed ferrocene/phenylboronic acid-modified bifunctional gold nanoparticles and the application in biosensing. Materials 2014, 7, 5554-5564. [CrossRef]

8. Inoue, H.; Anzai, J. Stimuli-sensitive thin films prepared by a layer-by-layer deposition of 2-iminobiotin-labeled poly(ethyleneimine) and avidin. Langmuir 2005, 21, 8354-8359. [CrossRef] [PubMed]

9. Anzai, J.; Kobayashi, Y.; Suzuki, Y.; Takeshita, H.; Chen, Q.; Osa, T.; Hoshi, T.; Du, X. Enzyme sensors prepared by layer-by-layer deposition of enzymes on a platinum electrode through avidin-biotin interaction. Sens. Actuators B 1998, 52, 3-9. [CrossRef]

10. Ballesta-Claver, J.; Ametis-Cabello, J.; Morales-Sanfrutos, J.; Megia-Fernandez, A.; Valencia-Miron, M.C.; Santoyo-Gonzalez, F.; Capitan-Vallvey, L.F. Electrochemiluminescent disposable cholesterol biosensor based on avidin-biotin assembling with the electroformed luminescent conducting polymer poly(luminol-biotinylated pyrrole). Anal. Chim. Acta 2012, 754, 91-98. [CrossRef] [PubMed]

11. Endo, Y.; Sato, K.; Sugimoto, K.; Anzai, J. Avidin/PSS membrane microcapsules with biotin-binding activity. J. Colloid Interface Sci. 2011, 360, 519-524. [CrossRef] [PubMed] 
12. Choi, Y.; Lee, G.; Ko, H.; Chang, Y.W.; Kang, M.; Ryun, J. Development of SPR biosensor for the detection of human hepatitis B virus using plasma-treated parylene-N film. Biosens. Bioelectron. 2014, 56, 286-294. [CrossRef] [PubMed]

13. Khan, M.; Park, S. Specific detection of avidin-biotin binding using liquid crystal droplets. Colloid Surf. B 2015, 127, 241-246. [CrossRef] [PubMed]

14. Kennedy, J.F.; Palva, P.M.G.; Corella, M.T.S.; Cavalcanti, M.S.M.; Coelho, L.C.B.B. Lectins, versatile protein of recognition: A review. Carbohydr. Polym. 1995, 26, 219-230. [CrossRef]

15. Becker, J.W.; Reeke, G.N., Jr.; Cunninngham, B.A.; Edelman, G.M. New evidence on the location of the saccharide-binding site of concanavalin A. Nature 1976, 259, 406-409. [CrossRef] [PubMed]

16. Mandel, D.K.; Kishore, N.; Brewer, C.F. Thermodynamics of lectin-carbohydrate interactions. Titration microcalorimetry measurements of the binding of N-linked carbohydrates and ovalbumin to concanavalin A. Biochemistry 1994, 33, 1149-1156. [CrossRef]

17. Zhang, S.Z.; Zhao, F.L.; Li, K.A.; Tong, S.Y. A study on the interaction between concanavalin A and glycogen by light scattering technique and its analytical application. Talanta 2001, 54, 333-342. [CrossRef]

18. Hoshi, T.; Akase, S.; Anzai, J. Preparation of multilayer thin films containing avidin through sugar-lectin interactions and their binding properties. Langmuir 2002, 18, 7024-7028. [CrossRef]

19. Sato, K.; Imoto, Y.; Sugama, J.; Seki, S.; Inoue, H.; Odagiri, T.; Hoshi, T.; Anzai, J. Sugar-induced disintegration of layer-by-layer assemblies composed of concanavalin A and glycogen. Langmuir 2005, 21, 797-799. [CrossRef] [PubMed]

20. Ballerstadt, R.; Evans, C.; McNichols, R.; Gowda, A. Concanavalin A for in vivo glucose sensing: A biotoxicity review. Biosens. Bioelectron. 2006, 22, 275-284. [CrossRef] [PubMed]

21. Anzai, J.; Kobayashi, Y.; Hoshi, T.; Saiki, H. A layer-by-layer deposition of concanavalin A and native glucose oxidase to form multilayer thin films for biosensor applications. Chem. Lett. 1999, 28, 365-366. [CrossRef]

22. Anzai, J.; Kobayashi, Y. Construction of multilayer thin films of enzymes by means of sugar-lectin interactions. Langmuir 2000, 16, 2851-2856. [CrossRef]

23. Hoshi, T.; Saiki, H.; Kuwazawa, S.; Tsuchiya, C.; Chen, Q.; Anzai, J. Selective permeation of hydrogen peroxide through polyelectrolyte multilayer films and its use for amperometric biosensors. Anal. Chem. 2001, 73, 5310-5315. [CrossRef] [PubMed]

24. Kobayashi, Y.; Anzai, J. Preparation and optimization of bienzyme multilayer films using lectin and glyco-enzymes for biosensor applications. J. Electroanal. Chem. 2001, 507, 250-255. [CrossRef]

25. Wilson, R.; Turner, A.P.F. Glucose oxidase: An ideal enzyme. Biosens. Bioelectron. 1992, 7, $165-185$. [CrossRef]

26. Campos, P.P.; Moraes, M.L.; Volpati, D.; Miranda, P.B.; Oliveira, O.N., Jr.; Ferreira, M. Amperometric detection of lactose using $\beta$-galactosidase immobilized in layer-by-layer films. ACS Appl. Mater. Interfaces 2014, 6, 11657-11664. [CrossRef] [PubMed]

27. Sato, K.; Yoshida, K.; Takahashi, S.; Anzai, J. pH- and sugar-sensitive layer-by-layer films and microcapsules for drug delivery. Adv. Drug Deliv. Rev. 2011, 63, 809-821. [CrossRef] [PubMed]

28. Yoshida, K.; Hasebe, Y.; Takahashi, S.; Sato, K.; Anzai, J. Layer-by-layer deposited nano- and micro-assemblies for insulin delivery: A review. Mater. Sci. Eng. C 2014, 34, 384-392. [CrossRef] [PubMed]

29. Bolls, K.M.; Cheng, F.; Burk-Rafel, J.; Dubey, M.; Ratner, D.M. Imaging analysis of carbohydrate-modified surfaces using Tof-SIMS and SPRi. Materials 2010, 3, 3948-3964. [CrossRef] [PubMed]

30. Díez-Pascual, A.M.; Shuttleworth, P.S. Layer-by-layer assembly of biopolyelectrolytes onto thermos/pH-responsive micro/nano-gels. Materials 2014, 7, 7472-7512. [CrossRef]

31. Kapetanakis, A.; Heise, A. Thermoresponsive glycopolypeptides with temperature controlled selective lectin binding properties. Eur. Polym. J. 2015, 69, 483-489. [CrossRef]

32. Sato, K.; Kodama, D.; Anzai, J. Electrochemical determination of sugars by use of multilayer thin films of ferrocene-appended glycogen and concanavalin A. Anal. Bioanal. Chem. 2006, 6, 1899-1904. [CrossRef] [PubMed]

33. Steiner, M.; Duerkop, A.; Wolfbeis, O.S. Optical methods for sensing glucose. Chem. Soc. Rev. 2011, 40, 4805-4839. [CrossRef] [PubMed]

34. Sato, K.; Takahashi, S.; Anzai, J. Layer-by-layer thin films and microcapsules for biosensors and controlled release. Anal. Sci. 2012, 28, 929-938. [CrossRef] [PubMed] 
35. Zeng, X.; Andrade, C.A.S.; Oliveira, M.D.L.; Sun, X. Carbohydrate-protein interactions and their biosensing applications. Anal. Bioanal. Chem. 2012, 402, 3161-3176. [CrossRef] [PubMed]

36. Takahashi, S.; Sato, K.; Anzai, J. Layer-by-layer construction of protein architectures through avidin-biotin and lectin-sugar interactions for biosensor applications. Anal. Bioanal. Chem. 2012, 402, 1749-1758. [CrossRef] [PubMed]

37. Li, H.; Wei, L.; Fang, P.; Yang, P. Recent advances in the fabrication and detection of lectin microarrays and their application in glycobiology analysis. Anal. Methods 2014, 6, 2003-2014. [CrossRef]

38. Chen, C.; Xie, Q.; Yang, D.; Xiao, H.; Fu, Y.; Tan, Y.; Yao, S. Recent advances in electrochemical glucose biosensors: A review. RSC Adv. 2013, 3, 4473-4491. [CrossRef]

39. Tian, K.; Prestgard, M.; Tiwari, A. A review of recent advances in nonenzymatic glucose sensors. Mater. Sci. Eng. C 2014, 41, 100-118. [CrossRef] [PubMed]

40. Takahashi, S.; Anzai, J. Phenylboronic acid monolayer-modified electrodes sensitive to sugars. Langmuir 2005, 21, 5102-5107. [CrossRef] [PubMed]

41. Palod, P.A.; Singh, V. Improvement in glucose biosensing response of electrochemically grown polypyrrole nanotubes by incorporating crosslinked glucose oxidase. Mater. Sci. Eng. C 2015, 55, 420-430. [CrossRef] [PubMed]

42. Egawa, Y.; Seki, T.; Takahashi, S.; Anzai, J. Electrochemical and optical sugar sensors based on phenylboronic acid and its derivatives. Mater. Sci. Eng. C 2011, 31, 1257-1264. [CrossRef]

43. Çiftçi, H.; Tamer, U. Functional gold nanorod particles on conducting polymer poly(3-octylthiophene) as non-enzymatic glucose sensor. React. Funct. Polym. 2012, 72, 127-132.

44. Anzai, J.; Kobayashi, Y.; Nakamura, N.; Hoshi, T. Use of Con A and mannose-labeled enzymes for the preparation of enzyme films for biosensors. Sens. Actuators B 2000, 65, 94-96. [CrossRef]

45. Palazzo, G.; Colafemmina, G.; Iudice, C.G.; Mallardi, A. Three immobilized enzymes acting in series in layer by layer assemblies: Exploiting the trehalase-glucose oxidase-horseradish peroxidase cascade reactions for the optical determination of trehalose. Sens. Actuators B 2014, 202, 217-223. [CrossRef]

46. Liu, X.; Ou, X.; Lu, Q.; Chen, S.; Wei, S. A biorecognition system for concanavalin a using a glassy carbon electrode modified with silver nanoparticles, dextran and glucose oxidase. Microchim. Acta 2015, 182, 797-803. [CrossRef]

47. Ye, B. A stable enzyme biosensor using concanavalin a complex of glucose oxidase for glucose determination. Anal. Lett. 1998, 31, 2349-2359. [CrossRef]

48. Russell, R.; Pishko, M.V.; Gefrides, C.C.; McShane, M.J.; Coté, G.L. A fluorescence-based glucose biosensor using concanavalin A and dextran encapsulated in a poly(ethylene glycol) hydrogel. Anal. Chem. 1999, 71, 3126-3132. [CrossRef] [PubMed]

49. Kobayashi, Y.; Hoshi, T.; Anzai, J. Glucose and lactate biosensors prepared by a layer-by-layer deposition of concanavalin A and mannose-labeled enzymes: Electrochemical response in the presence of electron mediators. Chem. Pharm. Bull. 2001, 49, 755-757. [CrossRef] [PubMed]

50. Chinnayelka, S.; McShene, M.J. Glucose-sensitive nanoassemblies comprising affinity-binding complexes trapped in fuzzy microshells. J. Fluoresc. 2004, 14, 585-595. [CrossRef] [PubMed]

51. Pickup, J.C.; Hussain, F.; Evans, N.D.; Rolinski, O.J.; Birch, D.J.S. Fluorescence-based glucose sensors. Biosens. Bioelectron. 2005, 20, 2555-2565. [CrossRef] [PubMed]

52. Li, F.; Wang, Z.; Chen, W.; Zhang, S. A simple strategy for one-step construction of bienzyme biosensor by in-situ formation of biocomposite film through electrodeposition. Biosens. Bioelectron. 2009, 24, 3030-3035. [CrossRef] [PubMed]

53. Li, W.; Yuan, R.; Chai, Y. Determination of glucose using pseudobienzyme channeling based on sugar-lectin biospecific interactions in a novel organic-inorganic composite matrix. J. Phys. Chem. C 2010, 114, 21397-21404. [CrossRef]

54. Li, W.; Yuan, R.; Chai, Y.; Zhong, H.; Wang, Y. Study of the biosensor based on platinum nanoparticles supported on carbon nanotubes and sugar-lectin biospecific interactions for the determination of glucose. Electrochim. Acta 2011, 56, 4203-4208. [CrossRef]

55. Zhong, X.; Yuan, R.; Chai, Y. Synthesis of chitosan-Prussian blue-graphene composite nanosheets for electrochemical detection of glucose based on pseudobienzyme channeling. Sens. Actuators B 2012, 162, 224-240. [CrossRef] 
56. Zhang, J.; Wang, C.; Chen, S.; Yuan, D.; Zhong, X. Amperometric glucose biosensor based on glucose oxidase-lectin biospecific interaction. Enzym. Microb. Technol. 2013, 52, 134-140. [CrossRef] [PubMed]

57. Chen, Z.; Xi, F.; Yang, S.; Wu, Q.; Lin, X. Development of a bienzyme system based on sugar-lectin biospecific interactions for amperometric determination of phenols and aromatic amines. Sens. Actuators $B$ 2008, 130, 900-907. [CrossRef]

58. Liu, L.; Chen, Z.; Yang, S.; Jin, X.; Lin, X. A novel inhibition biosensor constructed by layer-by-layer technique based on biospecific affinity for the determination of sulfide. Sens. Actuators B 2008, 129, 218-224. [CrossRef]

59. Pallarola, D.; Queralto, N.; Knoll, W.; Ceolín, M.; Azzaroni, O.; Battaglini, F. Redox-active concanavalin A: Synthesis, characterization, and recognition-driven assembly of interfacial architectures for bioelectronics application. Langmuir 2010, 26, 13684-13696. [CrossRef] [PubMed]

60. Cortez, M.L.; Pallarola, D.; Ceolín, M.; Azzaroni, O.; Battaglini, F. Ionic self-assembly of electroactive biorecognizable units: Electrical contacting of redox glycoenzymes made easy. Chem. Commun. 2012, 48, 10868-10870. [CrossRef] [PubMed]

61. Pallarola, D.; von Bildering, C.; Pietrasanta, L.I.; Queralto, N.; Knoll, W.; Battaglini, F.; Azzaroni, O. Recognition-driven layer-by-layer construction of multiprotein assemblies on surfaces: A biomolecular toolkit for building up chemoresponsive bioelectrochemical interfaces. Phys. Chem. Chem. Phys. 2012, 14, 11027-11039. [CrossRef] [PubMed]

62. Cortez, M.L.; Pallarola, D.; Ceolín, M.; Azzaroni, O.; Battaglini, F. Electron transfer properties of dual self-assembled architectures based on specific recognition and electrostatic driving forces: Its application to control substrate inhibition in horseradish peroxidase-based sensors. Anal. Chem. 2013, 85, 2414-2422. [CrossRef] [PubMed]

63. Sugawara, K.; Yugami, A.; Kadoya, T.; Hosaka, K. Electrochemically monitoring the binding of cancanavalin A and ovalbumin. Talanta 2011, 85, 425-429. [CrossRef] [PubMed]

64. Zhou, L.; Jiang, Y.; Gao, J.; Zhao, X.; Ma, L.; Zhou, Q. Oriented immobilization of glucose oxidase on graphene oxide. Biochem. Eng. J. 2012, 69, 28-31. [CrossRef]

65. Ansari, S.A.; Husain, Q. Immobilization of Kluyveromyces lactis $\beta$ galactosidase on concanavalin A layered aluminum oxide nanoparticles-Its future aspects in biosensor applications. J. Mol. Catal. B Enzym. 2011, 70, 119-126. [CrossRef]

66. Yao, H.; Hu, N. pH-switchable bioelectrocatalysis of hydrogen peroxide on layer-by-layer films assembled by cancanavalin A and horseradish peroxidase with electroactive mediator in solution. J. Phys. Chem. B 2010, 114, 3380-3386. [CrossRef] [PubMed]

67. Ali, M.; Ramirez, P.; Tahir, M.N.; Made, S.; Siwy, Z.; Neumann, R.; Tremel, W.; Ensinger, W. Biomolecular conjugation inside synthetic polymer nanopores via glycoprotein-lectin interactions. Nanoscale 2011, 3, 1894-1903. [CrossRef] [PubMed]

68. Song, Y.; Wang, Y.; Liu, H.; Wang, L. A novel tri-protein bio-interphase composed of cytochrome $c$, horseradish peroxides and concanavalin A: Electron transfer and electrocatalytics. Int. J. Electrochem. Sci. 2012, 7, 11206-11218.

69. Labib, M.; Hedström, M.; Amin, M.; Mattiasson, B. A novel competitive capacitive glucose biosensor based on concanavalin A-labeled nanogold colloids assembled on a polytyramine-modified gold electrode. Anal. Chim. Acta 2010, 659, 194-200. [CrossRef] [PubMed]

70. Li, F.; Feng, Y.; Yang, L.; Li, L.; Tang, C.; Tang, B. A selective novel non-enzyme glucose amperometric biosensor based on lectin-sugar binding on thionine modified electrode. Biosens. Bioelectron. 2011, 26, 2489-2494. [CrossRef] [PubMed]

71. Wang, X.; Hou, T.; Li, W.; Chen, M.; Li, F. Highly sensitive and selective electrochemical identification of D-glucose based on specific concanavalin A combined with gold nanoparticles signal amplification. Sens. Actuators B 2013, 185, 105-109. [CrossRef]

72. Song, Y.; Liu, H.; Tan, H.; Xu, F.; Jia, J.; Zhang, L.; Li, Z.; Wang, L. pH-switchable electrochemical sensing platform based on chitosan-reduced graphene oxide/concanavalin A layer for assay of glucose and urea. Anal. Chem. 2014, 86, 1980-1987. [CrossRef] [PubMed]

73. Lim, K.R.; Park, J.; Choi, H.N.; Lee, W. Gold glyconanoparticle-based colorimetric bioassay for the determination of glucose in human serum. Microchem. J. 2013, 106, 154-159. [CrossRef] 
74. Hu, B.; Zhang, L.; Chen, M.; Chen, M.; Wang, J. The inhibition of fluorescence resonance energy transfer between quantum dots for glucose assay. Biosens. Bioelectron. 2012, 32, 82-88. [CrossRef] [PubMed]

75. Paek, S.; Cho, I.; Kim, D.; Jeon, J.; Lim, G.; Paek, S. Label-free, needle-type biosensor for continuous glucose monitoring based on competitive binding. Biosens. Bioelectron. 2013, 40,38-44. [CrossRef] [PubMed]

76. Tang, D.; Li, Q.; Tang, J.; Su, B.; Chen, G. An enzyme-free quartz crystal microbalance biosensor for sensitive glucose detection in biological fluids based on glucose/dextran displacement approach. Anal. Chim. Acta 2011, 686, 144-149. [CrossRef] [PubMed]

77. Coulibaly, F.S.; Youan, B.C. Concanavalin A-Polysaccharides binding affinity analysys using a quartz crystal microbalance. Biosens. Bioelectron. 2014, 59, 404-411. [CrossRef] [PubMed]

78. Zhang, G.; Huang, M.J.; Ang, J.J.; Yao, Q.; Ning, Y. Label-free detection of carbohydrate-Protein interactions using nanoscale field effect transistor biosensors. Anal. Chem. 2013, 85, 4392-4397. [CrossRef] [PubMed]

79. Bhattarai, J.K.; Sharma, A.; Fujikawa, K.; Demchenko, A.V.; Stine, K.J. Electrochemical synthesis of nanostructured gold film for the study of carbohydrate-Lectin interactions using localized surface plasmon resonance spectroscopy. Carbohyd. Res. 2015, 405, 55-65. [CrossRef] [PubMed]

80. Silva, D.M.; Domngues, L. On the track for an efficient detection of Escherichia coli in water: A review on PCR-based methods. Ecotoxicol. Environ. Saf. 2015, 113, 400-411. [CrossRef] [PubMed]

81. Kuhn, K.G.; Falkenhorst, G.; Ceper, T.; Dalby, T.; Etchelberg, S.; Mølbak, K.; Krogfelt, K.A. Detection of antibodies to Campylobacter in humans using enzyme-linked immunosorbent assay: A review of the literature. Diagn. Microbiol. Infect. Dis. 2012, 74, 113-118. [CrossRef] [PubMed]

82. Gamella, M.; Campuzano, S.; Parrado, C.; Reviejo, A.J.; Pingarrón, J.M. Microorganisms recognition and quantification by lectin adsorptive affinity impedance. Talanta 2009, 78, 1303-1309. [CrossRef] [PubMed]

83. Chan, K.Y.; Ye, W.W.; Zhang, Y.; Xiao, L.D.; Leung, P.H.M.; Li, Y.; Yang, M. Ultrasensitive detection of E. coli O157:H7 with biofunctional magnetic bead concentration via nanoporous membrane based electrochemical immunosensor. Biosens. Bioelectron. 2013, 41, 532-537. [CrossRef] [PubMed]

84. Ma, F.; Rehman, A.; Liu, H.; Zhang, J.; Zhu, S.; Zeng, X. Glycosylation on quinine-fused polythiophene for reagentless and label-free detection of E. coli. Anal. Chem. 2015, 87, 1560-1568. [CrossRef] [PubMed]

85. Dechtrirat, D.; Gajovic-Eichelmann, N.; Wojcik, F.; Hartmenn, L.; Bier, F.F.; Scheller, F.W. Electrochemical displacement sensor based on ferrocene boronic acid tracer and immobilized glycan for saccharide binding proteins and E. coli. Biosens. Bioelectron. 2014, 58, 1-8. [CrossRef] [PubMed]

86. Springsteen, G.; Wang, B. A detailed examination of boronic acid-diol complexation. Tetrahedron 2001, 58, 5291-5300. [CrossRef]

87. Mahalingam, A.; Geonnotti, A.R.; Balzarini, J.; Kiser, P.F. Activity and safety of synthetic lectins based on benzoboroxole-functionalized polymers for inhibition of HIV entry. Mol. Pharm. 2011, 8, 2465-2475. [CrossRef] [PubMed]

88. Narla, S.N.; Pinnamaneni, P.; Nie, H.; Li, Y.; Sun, X. BSA-boronic acid conjugate as lectin mimetics. Biochem. Biophys. Res. Commun. 2014, 443, 562-567. [CrossRef] [PubMed]

89. Bull, S.; Davidson, M.G.; van den Elsen, J.H.; Fossey, J.S.; Jenkins, A.T.A.; Jiang, Y.; Kubo, Y.; Marken, F.; Sakurai, K.; Zhao, J.; et al. Exploiting the reversible covalent bonding of boronic acids: Recognition, sensing, and assembly. Acc. Chem. Res. 2013, 46, 312-326. [CrossRef] [PubMed]

90. Watahiki, R.; Sato, K.; Suwa, K.; Niina, S.; Egawa, Y.; Seki, T.; Anzai, J. Multilayer films composed of phenylboronic acid-modified dendrimers sensitive to glucose under physiological conditions. J. Mater. Chem. B 2014, 2, 5809-5817. [CrossRef]

91. Sato, K.; Takahashi, M.; Ito, M.; Abe, E.; Anzai, J. $\mathrm{H}_{2} \mathrm{O}_{2}$-induced decomposition of layer-by-layer films consisting of phenylboronic acid-bearing poly(allylamine) and poly(vinyl alcohol). Langmuir 2014, 30, 9247-9250. [CrossRef] [PubMed]

92. Wang, H.; Bie, Z.; Lü, C.; Liu, Z. Magnetic nanoparticles with dendrimer-assisted boronate avidity for the selective enrichment of trace glycoproteins. Chem. Sci. 2013, 4, 4298-4303. [CrossRef]

93. Wang, H.; Zhou, H.; Chen, B.; Mendes, P.M.; Fossey, J.S.; James, T.D.; Long, Y. A bis-boronic acid modified electrode for the sensitive and selective determination of glucose concentrations. Analyst 2013, 138, 7146-7151. [CrossRef] [PubMed] 
94. Suwa, K.; Nagasaka, M.; Niina, S.; Egawa, Y.; Seki, T.; Anzai, J. Sugar response of layer-by-layer films composed of poly(vinyl alcohol) and poly(amidoamine) dendrimer bearing 4-carboxyphenylboronic acid. Colloid Polym. Sci. 2015, 293, 1043-1048. [CrossRef]

95. Izumi, M.; Otsuki, A.; Nishihara, M.; Okamoto, R.; Kajihara, Y. Chemical synthesis of a synthetic analogue of the sialic acid-binding lectin siglec-7. ChemBioChem 2014, 15, 2503-2507. [CrossRef] [PubMed]

96. Wang, B.; Anzai, J. Recent progress in electrochemical HbA1c sensors: A review. Materials 2015, 8, 1187-1203. [CrossRef]

97. Sato, K.; Takahashi, M.; Ito, M.; Abe, E.; Anzai, J. Glucose-induced decomposition of layer-by-layer films composed of phenylboronic acid-bearing poly(allylamine) and poly(vinyl alcohol) under physiological conditions. J. Mater. Chem. B 2015, 3, 7796-7802. [CrossRef]

98. Lu, Q.; Lin, H.; Ge, S.; Luo, S.; Cai, Q.; Grimes, C.A. Wireless, remote-query, and high sensitivity Echerichia coli O157:H7 biosensor based on the recognition action of cocanavalin A. Anal. Chem. 2009, 81, 5846-5850. [CrossRef] [PubMed]

99. Lin, H.; Lu, Q.; Ge, S.; Cai, Q.; Grimes, C.A. Detection of pathogen Echerichia coli O157:H7 with a wireless magnetoelastic-sensing device amplified by using chitosan-modified magnetic $\mathrm{Fe}_{3} \mathrm{O}_{4}$ nanoparticles. Sens. Actuators B 2010, 147, 343-349. [CrossRef]

100. Koh, J.; Liu, S.; Zeng, W.; Zou, H.; Wang, L.; Suresh, V.; Beuerman, R.; Cao, D. Electron donating group substituted and $\alpha$-D-mannopyranoside directly functionalized polydiacetylene as a simplified bio-sensing system for detection of lectin and E. coli. Sens. Actuators B 2013, 178, 563-571. [CrossRef]

101. He, X.; Zhou, L.; He, D.; Wang, K.; Cao, J. Rapid and ultrasensitive, E. coli O157:H7 quantitation by combination of ligandmagnetic nanoparticles enrichment with fluorescent nanoparticles based two-color flow cytometry. Analyst 2011, 136, 4183-4191. [CrossRef] [PubMed]

102. Liu, X.; Lei, Z.; Liu, F.; Liu, D.; Wang, Z. Fabricating three-dimensional carbohydrate hydrogel microarray for lectin-mediated bacterium capturing. Biosens. Bioelectron. 2014, 58, 92-100. [CrossRef] [PubMed]

103. Da Silva, J.S.L.; Oliveira, M.D.L.; de Melo, C.P.; Andrade, C.A.S. Impedimetric sensor of bacteria toxins based on mixed (concanavalin A)/polyaniline films. Colloid Surf. B 2014, 117, 549-554. [CrossRef] [PubMed]

104. Ma, F.; Rehman, A.; Sims, M.; Zeng, X. Antimicrobial susceptibility assay based on the quantification of bacterial lipopolysaccharides via a label free lectin biosensors. Anal. Chem. 2015, 87, 4385-4393. [CrossRef] [PubMed]

105. Mandenius, C.; Wang, R.; Aldén, A.; Bergström, G.; Thebault, S.; Lutsch, C.; Ohlson, S. Monitoring of influenza virus hemagglutinin in process samples using weak affinity ligands and surface plasmon resonance. Anal. Chim. Acta 2008, 623, 66-75. [CrossRef] [PubMed]

106. Park, J.; Jin, S.I.; Kim, H.M.; Ahn, J.; Kim, Y.; Lee, E.G.; Kim, M.; Shin, Y. Monitoring change in refractive index of cytosol of animal cells on affinity surface under osmotic stimulus for label-free measurement of viability. Biosens. Bioelectron. 2015, 64, 241-246. [CrossRef] [PubMed]

107. Qi, P.; Zhang, D.; Wan, Y.; Lv, D. A facile approach to construct versatile signal amplification system for bacteria detection. Talanta 2014, 118, 333-338. [CrossRef] [PubMed]

108. Takahashi, S.; Anzai, J. Recent progress in ferrocene-modified thin films and nanoparticles for biosensors. Materials 2013, 6, 5742-5762. [CrossRef]

109. Oliveira, M.D.L.; Correia, M.T.S.; Diniz, F.B. A novel approach to classify serum glycoproteins from patients infected by dengue using electrochemical impedance spectroscopy analysis. Synth. Met. 2009, 159, 2162-2164. [CrossRef]

110. Avelino, K.Y.P.S.; Andrade, C.A.S.; de Melo, C.P.; Nogueira, M.L.; Correia, M.T.S.; Coelho, L.C.B.B.; Oliveira, M.D.L. Biosensor based on hybrid nanocomposite and CramoLL lectin for detection of dengue glycoproteins in real samples. Synth. Met. 2014, 194, 102-108. [CrossRef]

111. Luna, D.M.; Oliveira, M.D.L.; Nogueria, M.L.; Andrade, C.A.S. Biosensor based on lectin and membranes for detection of serum glycoproteins in infected patients with dengue. Chem. Phys. Lipids 2014, 180, 7-14. [CrossRef] [PubMed]

112. Fu, Y.; Callaway, Z.; Lum, J.; Wang, R.; Lin, J.; Li, Y. Exploiting enzyme catalysis in ultra-low ion media for impedance biosensing of avian influenza virus using a bare interdigitated electrode. Anal. Chem. 2014, 86, 1965-1971. [CrossRef] [PubMed] 
113. Yang, C.; Xu, C.; Wang, X.; Xiao, Z.; Gu, B. A displacement assay for the sensing of carbohydrate using zinc oxide biotracers. Electrochim. Acta 2012, 60, 50-54. [CrossRef]

114. Pandy, B.; Bhattarai, J.K.; Pornsuriyasak, P.; Fijikawa, K.; Catania, R.; Demchenko, A.V.; Stine, K.J. Square-wave voltammetry assays for glycoproteins on nanoporous gold. J. Electroanal. Chem. 2014, 717-718, 47-60. [CrossRef] [PubMed]

115. Liu, J.; Wang, J.; Wang, T.; Li, D.; Xi, F.; Wang, J.; Wang, E. Three-dimensional electrochemical immunosensor for sensitive detection of carcinoembryonic antigen based on monolithic and macroporous graphene foam. Biosens. Bioelectron. 2015, 65, 281-286. [CrossRef] [PubMed]

116. Ueda, K.; Fukase, Y.; Katagiri, T.; Ishikawa, N.; Irie, S.; Sato, T.; Ito, H.; Nakayama, H.; Miyagi, Y.; Tsuchiya, E.; et al. Targeted serum glycoproteomics for the discovery of lung cancer-associated glycosylation disorders using lectin-coupled protein chip assays. Proteomics 2009, 9, 2182-2192. [CrossRef] [PubMed]

117. Ding, C.; Qian, S.; Wang, Z.; Qu, B. Electrochemical cytosensor based on gold nanoparticles for the determination of carbohydrate on cell surface. Anal. Biochem. 2011, 414, 84-87. [CrossRef] [PubMed]

118. Hu, Y.; Zuo, P.; Ye, B. Label-free electrochemical impedance spectroscopy biosensor for direct detection of cancer cells based on the interaction between carbohydrate and lectin. Biosens. Bioelectron. 2013, 43, 79-83. [CrossRef] [PubMed]

119. Cancino-Bernardi, J.; Marangoni, V.S.; Faria, H.A.M.; Zocolotto, V. Detection of leukemic cells by using jacalin as the biorecognition layer: A new strategy for the detection of circulating tumor cells. ChemElectroChem 2015, 2, 963-969. [CrossRef]

120. Pei, Z.; Saint-Guirons, J.; Käck, C.; Ingemarsson, B.; Aastrup, T. Real-time analysis of the carbohydrates on cell surfaces using a QCM biosensor: A lectin-based approach. Biosens. Bioelectron. 2012, 35, 200-205. [CrossRef] [PubMed]

121. Liu, H.; Xu, S.; He, Z.; Deng, A.; Zhu, J. Supersandwich cytosensor for selective and ultrasensitive detection of cancer cells using aptamer-DNA concatamer-quantum dots probes. Anal. Chem. 2013, 85, 3385-3392. [CrossRef] [PubMed]

122. Zhang, X.; Teng, Y.; Fu, Y.; Zhang, S.; Wang, T.; Wang, C.; Jin, L.; Zhang, W. Lectin-based electrochemical biosensor constructed by functionalized carbon nanotubes for the competitive assay of glycan expression on living cancer cells. Chem. Sci. 2011, 2, 2353-2360. [CrossRef]

123. Fu, Y.; Lu, D.; Lin, B.; Sun, Q.; Liu, K.; Xu, L.; Zhang, S.; Hu, C.; Wang, C.; Xu, Z.; et al. Fluorescence assay for glycan expression on living cancer cells based on competitive strategy coupled with dual-functionalized nanobiocomposites. Analyst 2013, 138, 7016-7022. [CrossRef] [PubMed]

124. Chen, Z.; Liu, Y.; Wang, Y.; Zhao, X.; Li, J. Dynamic evaluation of cell surface N-glycan expression via an electrogenerated chemiluminescence biosensor based on concanavalin A-integrating gold-nanoparticle-modified $\mathrm{Ru}(\mathrm{bpy})_{3}{ }^{2+}$-doped silica nanoprobe. Anal. Chem. 2013, 85, 4431-4438. [CrossRef] [PubMed]

125. Chen, X.; Wang, Y.; Zhang, Y.; Chen, Z.; Liu, Y.; Li, Z.; Li, J. Sensitive electrochemical aptamer biosensors for dynamic cell surface $\mathrm{N}$-glycan evaluation featuring multivalent recognition and signal amplification on a dendrimer-graphene electrode interface. Anal. Chem. 2014, 86, 4278-4286. [CrossRef] [PubMed]

126. Cao, H.; Yang, D.; Ye, D.; Zhang, X.; Fang, X.; Zhang, S.; Liu, B.; Kong, J. Protein-inorganic hybrid nanoflowers as ultrasensitive electrochemical cytosensing interfaces for evaluation of cell surface sialic acid. Biosens. Bioelectron. 2015, 68, 329-335. [CrossRef] [PubMed]

127. Wang, Y.; Chen, Z.; Liu, Y.; Li, J. A functional glycoprotein competitive recognition and signal amplification strategy for carbohydrate-protein interaction profiling and cell surface carbohydrate expression evaluation. Nanoscale 2013, 5, 7349-7355. [CrossRef] [PubMed]

128. He, X.; Wang, X.; Jn, X.; Zhou, H.; Shi, X.; Chen, G.; Long, Y. Epimeric monosaccharide-quinone hybrids on gold electrodes toward the electrochemical probing of specific carbohydrate-protein recognitions. J. Am. Chem. Soc. 2011, 133, 3649-3657. [CrossRef] [PubMed]

129. Zeng, H.; Yu, J.; Jiang, Y.; Zeng, X. Complex thiolated mannose/quinone film modified on EQCM/Au electrode for recognizing specific carbohydrate-proteins. Biosens. Bioelectron. 2014, 55, 157-161. [CrossRef] [PubMed] 
130. Min, I.; Choi, L.; Ahn, K.; Kim, B.K.; Lee, B.Y.; Kim, K.S.; Choi, H.N.; Lee, W. Electrochemical determination of carbohydrate-binding proteins using carbohydrate-stabilized gold nanoparticles and silver enhancement. Biosens. Bioelectron. 2010, 26, 1326-1331. [CrossRef] [PubMed]

131. Loaiza, O.A.; Lamas-Ardisana, P.J.; Jubete, E.; Ochoteco, E.; Loinaz, I.; Cabañero, G.; García, I.; Penadés, S. Nanostructured disposable impedimetric sensors as tools for specific biomolecular interactions: Sensitive recognition of concanavalin A. Anal. Chem. 2011, 83, 2987-2995. [CrossRef] [PubMed]

132. Hu, F.; Chen, S.; Wang, C.; Yuan, R.; Xiang, Y.; Wang, C. Multi-wall carbon nanotube-polyaniline biosensor based on lectin-carbohydrate affinity for ultrasensitive detection of Con A. Biosens. Bioelectron. 2012, 34, 202-207. [CrossRef] [PubMed]

133. Wang, Z.; Sun, C.; Vegesna, G.; Liu, H.; Liu, Y.; Li, J.; Zeng, X. Glycosylated aniline polymer sensor: Amine to imine conversion on protein-carbohydrate binding. Biosens. Bioelectron. 2013, 46, 183-189. [CrossRef] [PubMed]

134. Guo, C.; Boullanger, P.; Jiang, L.; Liu, T. One-step immobilization of alkanethiol/glycolipid vesicles onto gold electrode: Amperometric detection of concanavalin, A. Colloid Surf. B 2008, 62, 146-150. [CrossRef] [PubMed]

135. Sugawara, K.; Kadoya, T.; Kuramiz, H. Electrochemical sensing of concanavalin A using a non-ionic surfactant with a maltose moiety. Anal. Chim. Acta 2014, 814, 55-62. [CrossRef] [PubMed]

136. Zhang, J.; Ruo, Y.; Chen, S.; Zhong, X.; Wu, X. A sandwich-like electrochemiluminescent biosensor for the detection of concanavalin a based on a C60-reduced graphene oxide nanocomposite and glucose oxidase functionalized hollow gold nanosheres. RSC Adv. 2014, 4, 48465-48471. [CrossRef]

137. Zhang, J.; Chen, S.; Ruo, Y.; Zhong, X.; Wu, X. An ultrasensitive electrochemiluminescent biosensor for the detection of concanavalin A based on poly(ethylenimine) reduced graphene oxide and hollow gold nanoparticles. Anal. Bioanal. Chem. 2015, 407, 447-453. [CrossRef] [PubMed]

138. Ou, X.; Tan, X.; Liu, X.; Lu, Q.; Chen, S.; Wei, S. A signal-on electrochemiluminescence biosensor for detecting Con A using phenoxy dextran-graphene-like carbon nitride as signal probe. Biosens. Bioelectron. 2015, 70, 89-97. [CrossRef] [PubMed]

139. Shi, J.; Cai, L.; Pu, K.; Liu, B. Synthesis and characterization of water-soluble conjugated glycopolymer for fluorescent sensing of concanavalin A. Chem. Asian J. 2010, 5, 301-308. [CrossRef] [PubMed]

140. Lim, K.R.; Ahn, K.; Lee, W. Detection of concanavalin A based on attenuated fluorescence resonance energy transfer between quantum dots and mannose-stabilized gold nanoparticles. Anal. Methods 2013, 5, 64-67. [CrossRef]

(C) 2015 by the authors; licensee MDPI, Basel, Switzerland. This article is an open access article distributed under the terms and conditions of the Creative Commons by Attribution (CC-BY) license (http://creativecommons.org/licenses/by/4.0/). 